\title{
Zhodnocení vlivu koroze žárově zinkované oceli na soudržnost hladkých prutů $s$ betonem tř́idy „NSC“
}

\section{The assessment of the impact of corrosion of galvanised steel on bond strength of plain bars with "NSC" concrete}

\author{
Pokorný P. ${ }^{1}$, Dobiáš D. ${ }^{1}$, Vokáč M. ${ }^{1}$, Kouřil M. ${ }^{2}$, Kubásek J. ${ }^{2}$ \\ 1 ČVUT Praha, Kloknerův ústav \\ ${ }^{2}$ VŠCHT Praha, Ústav kovových materiálů a korozního inženýrství \\ E-mail: Petr.Pokorny@cvut.cz
}

Článek shrnuje aspekty zkoušeni a ovlivňováni soudržnosti výztuži s betonem. Úzce se zaměřuje na hodnocení míry vlivu nevyhnutelné koroze povlaku žárového zinku v čerstvém betonu na samotnou soudržnost. Ovlivněni soudržnosti vlivem vývoje vodiku a expanznich koroznich produktio zinku je ověrováno na hladkých ocelových prutech. Povlak žárového zinku byl vytvoren konvenčni ponorovou technologií. Realizováno bylo normované zkoušení soudržnosti výztuže s betonem na krychlích (,,vytahovací zkouška“) dle ČSN 73 1328. V závěrech jsou diskutovány i jiné vlivy, které mohou mít dopad na vývoj soudržnosti, předevšim pak vliv obsahu chromanù v použitém cementu a samotná skladba vyloučeného povlaku.

\section{ÚVOD}

Koroze výztuže z uhlíkové oceli v betonu kontaminovaného chloridy je i v současnosti velice zásadním problémem korozního inženýrství. Protože rychlost šíření chloridové fronty zvlhčenou pórovitou strukturou betonu je obvykle vyšší než průběh karbonatace, doplácí na tento korozní problém především vyztužené betonové konstrukce $\mathrm{v}$ blízkosti dálnic a silnic (vliv použití rozmrazovacích solí) nebo konstrukce poblíž mořských nebo brakických vod [1-3].

Lokalizované korozní poškození způsobené nadkritickým množstvím chloridových anionů v blízkosti nechráněné výztuže $\mathrm{z}$ uhlíkové oceli vyvolává růst objemných korozních produktů železa. Tyto objemové změny poškozují okolní beton lokálními trhlinami a způsobují jeho odpadávání. Tato skutečnost rozsáhlé korozní poškození ještě urychluje [4-6].

Protože tento problém vyžaduje vždy včasná a nákladná sanační opatření, jsou dodnes diskutovány různé možnosti ochrany výztuže, které by zajistily
The paper summarises the aspects of testing and influencing of reinforcement-concrete bond strength. It is focusing on the assessment of the extent of influence of the inevitable corrosion of the zinc coat in fresh concrete. The impact on concrete bond strength induced by evolving hydrogen and expanding zinc corrosion products is verified on plain steel bars. The zinc coat was produced by a conventional hot-dip galvanising technology. Standardised prism tests according to ČSN 731328 ("pull-out test") were applied to test reinforcement-concrete concrete bond strength. The conclusion discusses also other impacts that might affect the cohesion progress, namely the impact of the contents of chromium (VI) compounds in the used concrete and the composition of the deposited coat.

požadovanou životnost staveb (někdy i na 100 let) bez nutnosti sanačních opatření. Nejčastěji se prodlužuje doba do aktivace uhlíkové oceli v kritických místech staveb zvyšováním krycí vrstvy betonu. Ovšem záměrné navyšování krycí vrstvy betonu má svoje technologické i ekonomické limity a nemůže zajistit vysokou životnost konstrukce $[1,3]$.

Obvyklé vysoké úspešnosti dosahuje katodická ochrana, ovšem tuto techniku nelze často využít všude a patří mezi nákladnější ochranná opatření $[1,4]$. Využití adsorbčních inhibitorů koroze uhlíkové oceli je velice diskutabilním řešením. Je totiž velice obtížné udržovat dostatečnou koncentraci inhibitorů na povrchu ocelové výztuže v průběhu návrhové doby životnosti konstrukce [5]. Úspěšné využití plnoprůřrezových korozivzdorných ocelí s podmínkou jejich nezokujeného povrchu je také bohužel pro stavební průmysl z ekonomického důvodu problematické [7]. Experimentální testování odolnosti uhlíkových ocelí plátovaných vhodným typem korozivzdorné oceli $\mathrm{s}$ nezokujeným povrchem prokázalo vysokou odolnost v modelových pórových roztocích si- 
mulujících zkarbonatovaný beton kontaminovaný chloridy [7]. Technologie výroby takových výztuží ovšem vyžaduje mimořádnou náročnost na kvalitu výroby.

Lze využít i jiné výztužné materiály (skleněná vlákna z alkalirezistentního skla, tkané textilie, drátky, polymerní vlákna apod.) ve formě soustředěné prutové i rozptýlené vláknové výztuže. Ovšem takto koncipovaný stavební beton často nemůže dosáhnout mechanických vlastností betonů vyztužených konvenční výztuží s uhlíkové oceli [2,3].

V současnosti je stále diskutována ochrana výztuže z běžné uhlíkové oceli povlaky. Vhodný neporézní povlak z teoretického hlediska může svým bariérovým mechanismem prodloužit dobu do aktivace povrchu oceli vlivem chloridových anionů. Povlakování ocelí je navíc univerzálním a většinou ekonomickým způsobem ochrany oceli. Důležité ovšem je, na rozdíl od atmosfér, aby povlak vykazoval odolnost $\mathrm{v}$ alkalickém prostředí betonu (pH pórového roztoku může být i vyšší než 13) a nesnižoval soudržnost výztuže s betonem [8].

Z pohledu ekonomických a technologických podmínek, př́ípadně okrajových podmínek nejvyšší možné tloušt'ky a kvality povlaku lze výztuž opatřovat povlaky na organické bázi (nejčastěji epoxidy, méně pak PVC), nebo povlaky vzniklými technologií žárového zinková- ní ponorem [9-13]. V mnoha experimentálních studiích bylo jednoznačně ověřeno, že žebírková výztuž s epoxidovým povlakem vykazuje sníženou soudržnost s betonem [14-18]. Důvodem k tomuto jevu může být omezení vzniku slabých vazebných interakcí mezi povlakem a cementovým tmelem nebo pouze nízká materiálová tuhost epoxidového povlaku, kterým se musí vnitřní síly přenést z oceli do betonu [19].

\section{Problematika výztuže žárově zinkované ponorem}

V některých studiích vykazuje sníženou soudržnost $\mathrm{s}$ betonem i žárově zinkovaná výztuž. Autoři, kteři zaznamenali tuto skutečnost svými experimenty, vysvětlují nesoudržnost zinkované výztuže s betonem změnou pórovitosti cementového tmelu na fázovém rozhraní povlaku žárového zinku a betonu [20, 21]. Zvýšení pórovitosti vyvolá vznikající vodík, který je produktem katodické korozní reakce rozpouštění zinku v alkalickém prostředí čerstvého cementového tmelu (obvyklé pH 13,0) viz (1) [22, 23]:

$$
2 \mathrm{H}_{2} \mathrm{O}+2 \mathrm{e}^{-} \rightarrow 2 \mathrm{OH}^{-}+\mathrm{H}_{2}
$$

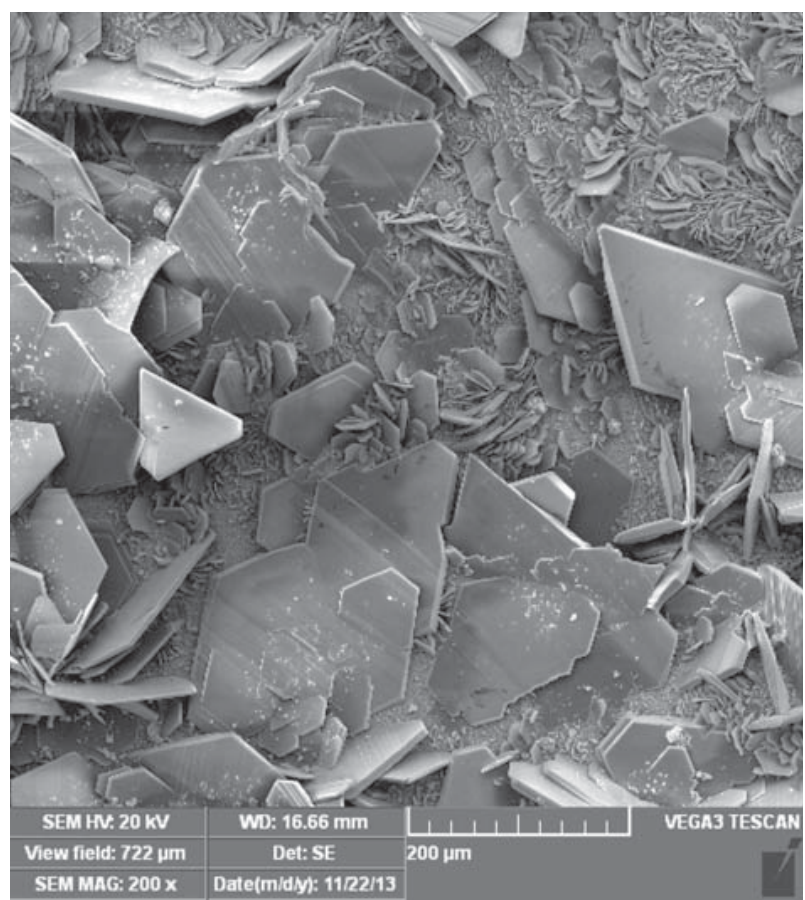

Obr. 1. Krystaly dihydrátu bis(trihydroxidozinečnatanu) vápenatého na povrchu zinkované oceli po 6 dnech expozice v modelovém pórovém roztoku o pH 12,6 (nasycený roztok $\left.\mathrm{Ca}(\mathrm{OH})_{2}\right)$ [34]

Fig. 1. $\mathrm{Ca}\left[\mathrm{Zn}(\mathrm{OH})_{3}\right]_{2} \cdot 2 \mathrm{H}_{2} \mathrm{O}$ crystals on the galvanized steel surface after 6 days of exposure in model pore solution (pH 12.6)

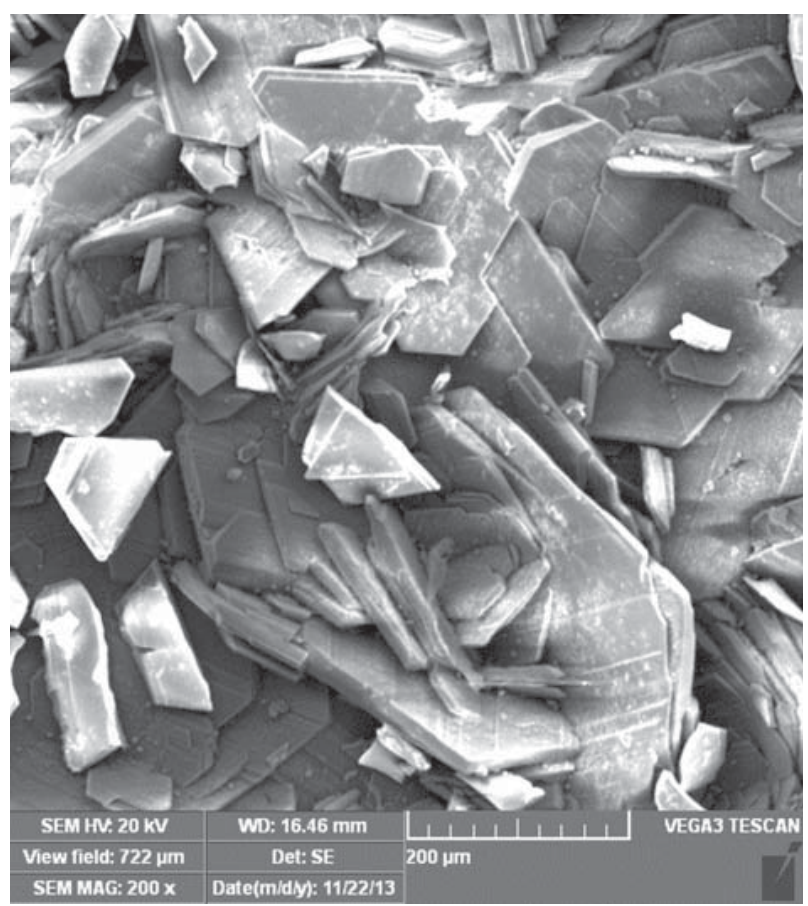

Obr. 2. Krystaly dihydrátu bis(trihydroxidozinečnatanu) vápenatého na povrchu zinkované oceli po 6 dnech expozice v modelovém pórovém roztoku o pH 13,0 (nasycený roztok $\mathrm{Ca}(\mathrm{OH})_{2}$ s príidavkem $\left.\mathrm{KOH}\right)$ [34]

Fig. 2. $\mathrm{Ca}\left[\mathrm{Zn}(\mathrm{OH})_{3}\right]_{2} \cdot 2 \mathrm{H}_{2} \mathrm{O}$ crystals on the galvanized steel surface after 6 days of exposure in model pore solution (pH 13) 
Anodický korozní děj, tj. anodické korozní rozpouštění zinku ve výše zmíněném alkalickém prostředí, tedy i za prrítomnosti $\mathrm{Ca}^{2+}$ kationtů lze popsat následujícími dílčími reakcemi (2), přičemž první z uvedených dílčích reakcí se odehrává na povrchu kovu a druhá již v samotném elektrolytu [22-26]:

$$
\begin{aligned}
& \mathrm{Zn}+2 \mathrm{OH}^{-} \rightarrow \mathrm{Zn}(\mathrm{OH})_{2}+2 \mathrm{e}^{-} \\
& \mathrm{Zn}(\mathrm{OH})_{2}+2 \mathrm{OH}^{-} \rightarrow\left[\mathrm{Zn}(\mathrm{OH})_{4}\right]^{2-}
\end{aligned}
$$

Komplexní forma zinečnatých anionů se hromadí u povrchu zinkované oceli, protože difúze těchto ionů od povrchu kovu je př́lišs pomalá. Po překročení kritické koncentrace těchto iontů $\mathrm{v}$ elektrolytu na fázovém rozhraní se zinkovnou ocelí dochází k precipitaci $\mathrm{ZnO}$ dle (3) [24-29]:

$$
\left[\mathrm{Zn}(\mathrm{OH})_{4}\right]^{2-} \rightarrow \mathrm{ZnO}+2 \mathrm{OH}^{-}+\mathrm{H}_{2} \mathrm{O}
$$

Na povrchu zinku se tvoří porézní vrstva složená ze směsných krystalů $\mathrm{ZnO}$ a $\varepsilon-\mathrm{Zn}(\mathrm{OH})_{2}$. Pokud ovšem dochází ke korozi zinku za př́tomnosti $\mathrm{Ca}^{2+}$, konkuruje precipitaci $\mathrm{ZnO}$ (3) precipitace dihydrátu bis(trihydroxidozinečnatanu) vápenatého podle (4) $[26,27,30,31$, 32].

$$
\begin{aligned}
& 2 \mathrm{Zn}(\mathrm{OH})_{2}+2 \mathrm{H}_{2} \mathrm{O}+\mathrm{Ca}(\mathrm{OH})_{2} \rightarrow \\
& \rightarrow \mathrm{Ca}\left[\mathrm{Zn}(\mathrm{OH})_{3}\right]_{2} \cdot 2 \mathrm{H}_{2} \mathrm{O}
\end{aligned}
$$

Podle některých autorů zaručuje tento hydrát tvorbu neporézního povlaku zajišstujícího přechod koroze zinkového povlaku do pasivního stavu [27, 31]. Jiní ovšem přisuzují dokonalejší ochranu povrchu zinkované oceli povlaku $\mathrm{ZnO}$ (s menším podílem $\varepsilon-\mathrm{Zn}(\mathrm{OH})_{2}$ ) než často sledované porézní struktuře $\mathrm{Ca}\left[\mathrm{Zn}(\mathrm{OH})_{3}\right]_{2} \cdot 2 \mathrm{H}_{2} \mathrm{O}$ [33]. Vzhled deskovitých krystalů $\mathrm{Ca}\left[\mathrm{Zn}(\mathrm{OH})_{3}\right]_{2} \cdot 2 \mathrm{H}_{2} \mathrm{O}$ vyloučených na žárově pozinkované oceli po šestidenní expozici v modelových pórových roztocích betonu o $\mathrm{pH}$ 12,6 a 13,0 zobrazuje Obr. 1 a Obr. 2 [34].

Protože při expozicích pozinkované oceli v modelovém pórovém roztoku betonu o $\mathrm{pH}$ 12,6 (nasycený roztok $\mathrm{Ca}(\mathrm{OH})_{2}$ - simulace idealizovaného betonu bez přítomnosti oxidů alkalických kovů ve slínku) lze na počátku expozice u zinkované oceli zaznamenat $\mathrm{E}_{\text {kor }} \sim-1100$ až $-1200 \mathrm{mV}$ vs. SCE [33], což je nižší potenciál než teoreticky vypočtený rovnovážný potenciál pro redukci vodíku při $\mathrm{pH} 14\left(\mathrm{E}_{\mathrm{rov}}=-1070 \mathrm{mV}\right.$ vs. $\mathrm{SCE}$ ) [35]. Lze se tedy úspěšně domnívat, že koroze žárově zinkované oceli je v čerstvém betonu třídy "NSC" ("Normal Strength Concrete") z čistého portlandského cementu (CEM I) doprovázena vždy vývojem vodíku.

\section{Soudržnost žárově zinkované výztuže s betonem}

Zvýšení pórovitosti cementového tmelu na fázovém rozhraní musí nutně vést $\mathrm{k}$ omezení působení slabých vazebných interakcí působících na krátkou vzdálenost mezi oběma materiály [2]. Nejenom tato skutečnost ovšem může snížit soudržnost zinkované výztuže s betonem. Negativní vliv může mít i snížení tloušt'ky zinkového povlaku, expanzivní efekt růstu korozních produktů z $\mathrm{Ca}\left[\mathrm{Zn}(\mathrm{OH})_{3}\right]_{2} \cdot 2 \mathrm{H}_{2} \mathrm{O}$ [19-21] nebo vliv difúze zinečnatanů do cementového tmelu (zinečnatany podobně jako oxid olovnatý zpomalují proces tuhnutí betonu a rovněž zhoršují mechanické vlastnosti betonu $\mathrm{v}$ kontaminované oblasti [36-40]).

Ovšem pohled na soudržnost zinkované výztuže $\mathrm{s}$ betonem není jednotný. Někteří odborníci naopak tvrdí, že korozní produkty zinku jsou schopny snadno difundovat od povrchu výztuže a vyplňovat porézní strukturu cementového tmelu. Tímto efektem vysvětlují naměřenou zvýšenou soudržnost zinkované výztuže s betonem po 28 dnech zrání betonu [41]. Jiní jsou opačného názoru a shledávají, že porézní struktura cementového tmelu na fázovém rozhraní je po celou dobu zrání betonu téměř nezměněna [42].

Dodones není zcela jasné, zda koroze zinkované oceli doprovázená vývojem vodíku a růstem korozních produktů na majoritní bázi $\mathrm{Ca}\left[\mathrm{Zn}(\mathrm{OH})_{3}\right]_{2} \cdot 2 \mathrm{H}_{2} \mathrm{O}$ má negativní vliv na vývoj soudržnosti s betonem.

Experimentálním ověřováním soudržnosti výztuže $s$ betonem rozumíme vytváření smykových napětí na rozhraní výztuže s betonem ( $\tau[\mathrm{MPa}])$, různými způsoby dle uspořádání experimentu, vyvolávajících posun výztuže o 0,001 mm (dle ČSN 731328 [43] nebo ČSN 731333 [44]). Tyto normy a jiné odborné standardy (AISI, RILEM apod.) doporučují ověřování soudržnosti bud' zkouškou soudržnosti na trámcích, nebo zkouškou soudržnosti na kvádrech či krychlích (tzv. „vytahovací zkouška“). Druhé zmíněné uspořádání je z technologického a ekonomického hlediska upřednostňováno. Je důležité si uvědomit, že zmiňované předpisy a doporučení ověrují vliv různé geometrie povrchu zkoušené výztuže na soudržnost s betonem (žebírka, vtisky apod.). Neexistuje předpis realizace experimentů pro stanovení soudržnosti povlakované výztuže s betonem [21,34].

Je ale zřejmé, že na soudržnost výztuže s betonem mají vliv celkem tři faktory (5). První faktor $\left(\mathrm{f}_{\mathrm{ad}}\right)$ zohledňuje vliv slabých vazebných interakcí mezi výztuží a betonem a právě on může být narušen zmiňovanými vlivy, tj. zvýšením pórovitosti cementového tmelu na fázovém rozhraní a tvorbou korozních produktů $\mathrm{z} \mathrm{Ca}\left[\mathrm{Zn}(\mathrm{OH})_{3}\right]_{2} \cdot 2 \mathrm{H}_{2} \mathrm{O}[19,21]$. Protože povrch i žebírkových výztuží (mimo vlastní žebírka) nemůže být dokonale hladký, je důležité zavádět při zkoušení i třecí faktor $\mathrm{f}_{\mathrm{f}}$. Nejzásadnější vliv na soudržnost $\mathrm{s}$ betonem má ovšem žebírkování, tj. mechanického provázání geometrie výztuže s cementovým tmelem $\left(f_{\text {mech }}\right)$.

$$
B_{S}=f_{a d}+f_{f}+f_{\text {mech }}
$$

Z výše uvedeného vyplývá, že při zkoušení soudržnosti povlakovaných výztuží s betonem při podezření, že vytvořený povlak může s betonem na základě různých 
mechanizmů vytvářet nesoudržné spojení, je nutné testovat pouze hladkou výztuž. Navíc je důležité, aby hladká výztuž byla kotvena do osy zkušebních těles, tak aby v žádném stykovém místě nepůsobila na beton tlakem [19]. Dále je důležité, aby povrch pozinkované výztuže neobsahoval defekty, které by uměle navyšovaly drsnost povrchu hladké výztuže (hrudky a krupice [45, 46]), tj. aby pozinkování ponorem bylo provedeno řádně. Za těchto podmínek lze zkoušet dle uvedených předpisů vliv koroze žárově zinkované výztuže na soudržnost

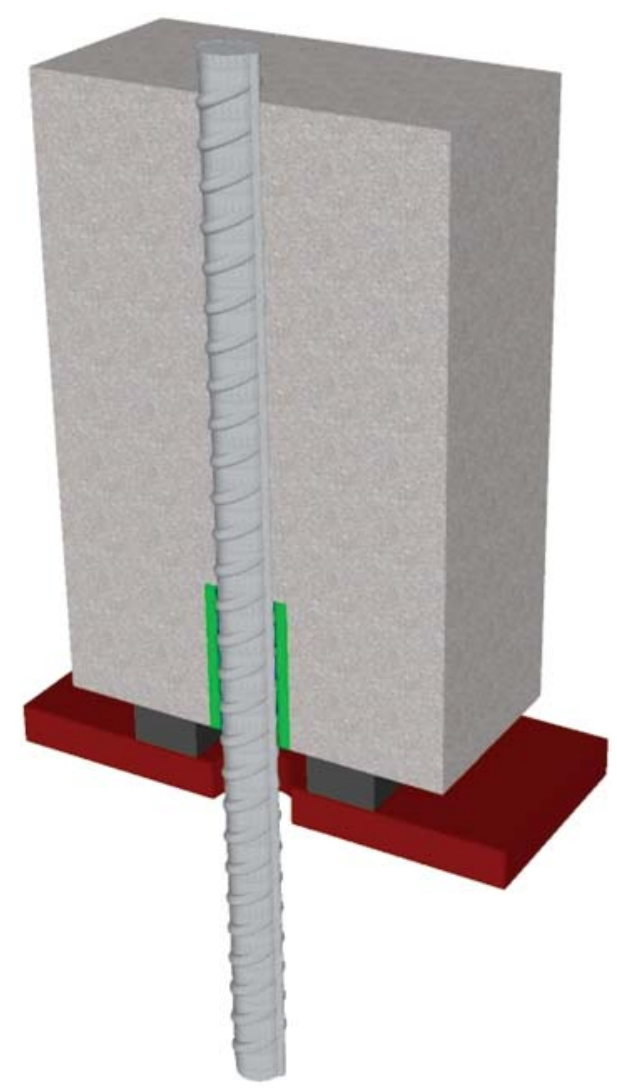

Obr. 3. Uspořádání zkoušky soudržnosti na kvádrech dle ČSN 731328 („vytahovací zkouška“) [43]

Fig. 3. Pull-out test adjustment

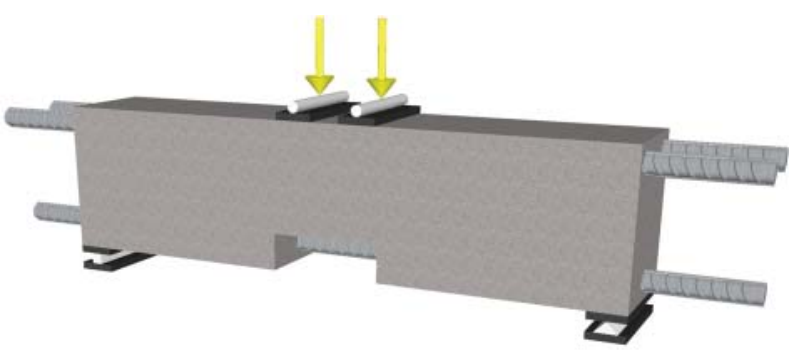

Obr. 4. Uspořádání zkoušky soudržnosti na trámcích dle ČSN 731328 („ohybová zkouška“) [43] Fig. 4. Bend test adjustment s betonem, a to po době zrání 28 dní, což je standardní stáří betonu pro stanovení pevnosti, resp. pevnostní tř́idy betonu.

Literatura zabývající se soudržností hladké i žebírkové žárově pozinkované výztuže s betonem je poměrně hojná. Výsledky ryze odborné literatury chronologicky shrnuje Tab. 1. [19, 34]. Ani z těchto výsledků nelze vytvořit jednoznačné závěry. $V$ některých případech vychází u výztuží soudržnost snížená, ale v jiných naopak obvykle srovnatelná nebo mírně zvýšená [21,34].

Existuje ovšem i značné množství srovnávacích studií, možná účelově zanesených na různých webových stránkách, které zaznamenávají srovnávací zkoušky soudržnosti pozinkovaných a nepozinkovaných výztuží. Výsledky obvykle ukazují mimořádnou soudržnost pozinkované výztuže $(1,5$ až $2 \times$ větší než u výztuže bez povlaku) s betonem po 28 dnech zrání vzorků [47-49]. Ovšem takové výsledky nelze logicky vysvětlit a postrádají na objektivnosti. Důvodem je především neúplná specifikace experimentu a vnějších faktorů majících vliv na soudržnost výztuže s betonem. Často totiž chybí volba a bližší popis uspořádání zkoušky soudržnosti, specifikace normativu zkoušení, charakteristika případných vázacích prvků zkoušených výztuží, dokumentace stavu povrchu, metalografická analýza povlaku žárového zinku a složení podkladové oceli, stanovení složení použitého cementu. Často není definován ani vodní součinitel betonové směsi. Obvykle nebývají definovány ani mechanické vlastnosti ztvrdlého betonu, popis způsobu jeho uložení a ošetřování, teplota vzduchu v průběhu realizace zkoušek soudržnosti apod.

V některé literatuře se uvádí, že na vývoj soudržnosti zinkované výztuže $\mathrm{s}$ betonem může mít vliv i obsah $\mathrm{CrO}_{4}{ }^{2-} \mathrm{v}$ cementu. Obsah chromanů v rozsahu 100-200 ppm (přepočteno na suchý cement bez kameniva) může zamezit korozi povlaku žárového zinku $\mathrm{v}$ aktivním stavu na počátku expozice $\mathrm{v}$ čerstvém betonu [50-52]. Z tohoto důvodu je nutné konzultovat i vliv $\mathrm{CrO}_{4}{ }^{2-}$ $\mathrm{v}$ použitém cementu na vývoj soudržnosti zinkované výztuže s betonem. Př́ídavky chromanů do betonu jsou z ekonomických, ale především ekologických důvodů absolutně nepřijatelné. Vyluhovatelnost chromanů z betonu nesmí podle současných a platných evropských směrnic přesáhnout $2 \mathrm{ppm}$. Navíc př́́davky chromanů mají podobně jako zinečnatany negativní vliv na vývoj mechanických vlastností betonu [51].

Předkládaný článek popisuje experimentální ověření vlivu koroze žárově zinkované oceli na soudržnost $\mathrm{s}$ betonem. Zkoušení bylo realizováno na hladkých prutech žárově zinkovaných běžným ponorem, kotvených do os zkušebních krychlí (zvolena "vytahovací zkouška"). Článek uveřejňuje detailně všechny výše uvedené okrajové podmínky zkoušení soudržnosti. Diskutuje nejen vliv koroze povlaku zinku, ale rovněž i vliv skladby a složení povlaku a dále složení cementu na soudržnost s betonem. 
Tab. 1. Srovnání dosavadních zkoušek soudržnosti žárově zinkované oceli s betonem / Summary of previous works focused on galvanized steel/concrete bond strength

\begin{tabular}{|c|c|c|c|c|c|c|}
\hline Autor & $\begin{array}{c}\text { Rok } \\
\text { publikace }\end{array}$ & Druh výztuže & $\begin{array}{c}\text { Uspořádání } \\
\text { zkoušky }\end{array}$ & $\begin{array}{l}\text { Počet } \\
\text { vzorků }\end{array}$ & $\begin{array}{c}\text { Doba zrání } \\
\text { betonu }\end{array}$ & \begin{tabular}{|c|} 
Srovnání soudržnosti \\
s nepovlakovanou výztuží
\end{tabular} \\
\hline Slater & 1920 & žebírková i hladká & "vytahovací z." & 28 & 28 dní; 6 měsíců & snížená \\
\hline Schmeer & 1920 & hladká & "vytahovací z." & 50 & 28 dní; 3 a 6 měsíců & zvýšená \\
\hline Brodbeck & 1954 & žebírková i hladká & "vytahovací z." & 24 & $1 ; 3$ a 12 měsíců & zvýšená \\
\hline Bird & 1962 & hladká & "ohybová z." & - & - & snížená \\
\hline Bresler & 1962 & hladká & "ohybová z." & 40 & 28 dní & srovnatelná \\
\hline Hofsoy & 1965 & žebírková & "vytahovací z." & 60 & 28 dní & snížená \\
\hline Yeomans & 1994 & žebírková i hladká & "ohybová z." & 12 & 35 dní & mírně snížená \\
\hline Kayali & 1995 & žebírková & "ohybová z." & 12 & 28 dní & srovnatelná \\
\hline Kayali & 2000 & žebírková & "ohybová z." & 30 & 28 dní & srovnatelná \\
\hline Sistonen & 2001 & žebírková & "vytahovací z." & 30 & 25-37 dní & mírně snížená \\
\hline Hamad & 2005 & žebírková & "ohybová z." & 12 & 28 dní & mírně snížená \\
\hline Ryant & 2008 & hladká & "vytahovací z." & 15 & 28 dní & snížená \\
\hline Maldonado & 2010 & žebírková & "vytahovací z." & - & 28 dní & snížená/Zvýšená* \\
\hline Abdulkareem & 2011 & žebírková & "vytahovací z." & 35 & 28 dní & srovnatelná \\
\hline
\end{tabular}

* podle druhu použité betonové směsi

\section{EXPERIMENTÁLNÍ ČÁST}

Pro př́ípravu zkušebních těles byla použita receptura naznačená v Tab. 2. Přičemž uvedené navážky jsou pro přípravu $1 \mathrm{~m}^{3}$ betonu třídy NSC (,Normal Strength Concrete"). Bylo použito směsného cementu (CEM II) a dvou druhů kameniva rozdělených podle hrubosti (DTK - drobné těžené kamenivo s průměrem

Tab. 2. Detailní rozpis receptury př́ípravy $1 \mathrm{~m}^{3}$ betonu pro zkoušky soudržnosti výztuže s betonem a pro kontrolní zkoušky pevnosti betonu v tlaku / Composition of the concrete

\begin{tabular}{|l|c|}
\hline Složka betonu: specifické označení & Množství \\
\hline cement: CEM II/B-S 32,5 R (Č́́žkovice) & $360 \mathrm{~kg}$ \\
\hline kamenivo 1: DTK 0/4 Kaznějov & $669 \mathrm{~kg}$ \\
\hline kamenivo 2: HTK 8/16 Dobřín & $1241 \mathrm{~kg}$ \\
\hline superplastifikátor: Optima 208 & $1,90 \mathrm{~kg}$ \\
\hline záměsová voda & 1441 \\
\hline
\end{tabular}

Tab. 3. Výsledky chemické analýzy složení použitého cementu metodou XRF, obsah anionů $\mathrm{Cl}^{-}$a $\mathrm{CrO}_{4}^{2-}$ byl stanoven metodou ICP-OES z výluhu použitého cementu (všechny výsledky jsou uvedeny v hm. \%) / Chemical analysis of the concrete

\begin{tabular}{|c|c|c|c|c|c|c|c|c|c|}
\hline $\mathbf{C a O}$ & $\mathbf{S i O}_{2}$ & $\mathbf{A l}_{2} \mathbf{O}_{\mathbf{3}}$ & $\mathbf{F e}_{2} \mathbf{O}_{\mathbf{3}}$ & $\mathbf{S O}_{3}$ & $\mathbf{M g O}$ & $\mathbf{N a}_{\mathbf{2}} \mathbf{O}$ & $\mathbf{K}_{2} \mathbf{O}$ & $\mathbf{C l}^{-}$ & $\mathbf{C r O}_{4}{ }^{2-}$ \\
\hline 55,8 & 26,2 & 4,8 & 3,1 & 2,4 & 4,1 & 0,3 & 0,8 & 0,069 & $\sim 1,1 \cdot 10^{-3}$ \\
\hline
\end{tabular}


$57 \mathrm{~N}$; doba expozice 15 min při teplotě $75^{\circ} \mathrm{C}$ ) a mořeny v zředěné kyselině chlorovodíkové (15 hm. \%; doba expozice 2 minuty). V komerční zinkovně proběhlo opětovné odmaštění (roztok $\mathrm{NaOH}$ ) a rovněž i moření v HCl (uvedeno na základě ústního sdělení zaměstnanců zinkovny).

Pro zhodnocení tloušt'ky a skladby povlaku žárového zinku na ocelovém prutu byl nejdříve analyzován obsah uhlíku a dalších nečistot v konstrukční oceli. $\mathrm{K}$ tomuto účelu byl segmentovaný vzorek poskytnut $\mathrm{k}$ bodové analýze složení na optické emisní spektroskopii buzené doutnavým výbojem (GDS-OES), realizované na přístroji Horiba JobinYvon GD Profiler II. Výsledky této analýzy zobrazuje Tab. 4.

Tab. 4. Výsledky obsahu uhlíku a ostatních prvků v konstrukční oceli použitých prutů (všechny výsledky jsou uvedeny v hm. \%) / Chemical composition of substrate steel

\begin{tabular}{|c|c|c|c|c|c|c|c|}
\hline $\mathbf{C}$ & $\mathbf{S i}$ & $\mathbf{P}$ & $\mathbf{M n}$ & $\mathbf{S}$ & $\mathbf{C u}$ & $\mathbf{C r}$ & $\mathbf{N i}$ \\
\hline 0,11 & 0,24 & 0,01 & 0,56 & 0,03 & 0,22 & 0,05 & 0,08 \\
\hline
\end{tabular}

K zhodnocení vizuálního vzhledu a složení samotného povlaku žárového zinku byl snímkován příčný řez povlaku pod optickým mikroskopem (Arsenal AM2-TDV 530) a elektronovým mikroskopem TESCAN Vega - 3LMU s EDS analyzátorem. K zhodnocení sklady jednotlivých intermetalických fází $\mathrm{Fe}$ - Zn v povlaku byla využita bodová EDS analýza. Metalografický výbrus příčného řezu byl realizován s využitím brusných papírů P60 - P2400 (bruska: LaboPol-25). Leštění probíhalo s využitím diamantových past a zviditelnění skladby povlaku bylo realizováno leptadlem nital (2 hm. \%).

Vzorky betonu pro zkoušení pevnosti v tlaku (krychelná pevnost, dle norem ČSN EN 12390-3 [54] a ČSN EN 12390-7 [55]) a soudržnosti výztuže s betonem byly vyrobeny $\mathrm{v}$ laboratoři technologie betonu Kloknerova ústavu. Využita byla horizontální laboratorní míchačka a každá záměs měla objem 251 . Celkem byly namíchány dvě záměsi, označené jako 1 a 2 . Z každé záměsi byly vyrobeny 3 krychle o hraně $150 \mathrm{~mm}$ pro zkoušky pevnosti betonu $\mathrm{v}$ tlaku a 6 krychlí pro zkoušky soudržnosti výztuže s betonem. Přičemž bylo použito vždy tří vzorků žárově zinkovaných hladkých prutů a tří vzorků nepovlakovaných hladkých prutů.

Pro zkoušení soudržnosti hladkých prutů s betonem byl zvolen následující postup (dle ČSN 73 1328). Zkušební krychle se osadila na hobrovou desku uloženou na ocelové desce zkušebního prrípravku. Obě desky jsou opatřeny otvorem o průměru $25 \mathrm{~mm}$. Tímto otvorem se provlékl delší konec výztuže vyčnívající z krychle a upnul se do čelistí zkušebního stroje MTS $500 \mathrm{kN}$ (Obr. 5.). Na druhý konec výztuže se opřel snímač posunu LVDT B20, který spočíval svou základnou na krychli (Obr. 6.).
Síla vytahující výztuž z krychle se zvětšovala v deseti stupních (velikost stupně 2,5kN) s vyčkáváním 30 sekund na každém stupni. Mezi jednotlivými stupni se zvyšovala plynule rychlostí $0,125 \mathrm{kN} / \mathrm{s}$. Pokud nenastalo vytažení výztuže do 10 stupně zatěžování, na konci desátého stupně se síla dále plynule zvyšovala rychlostí $0,125 \mathrm{kN} / \mathrm{s}$ až do vytržení výztuže z krychle. Průběh časové závislosti vývoje zatěžovací síly je shrnut na Obr. 7 .

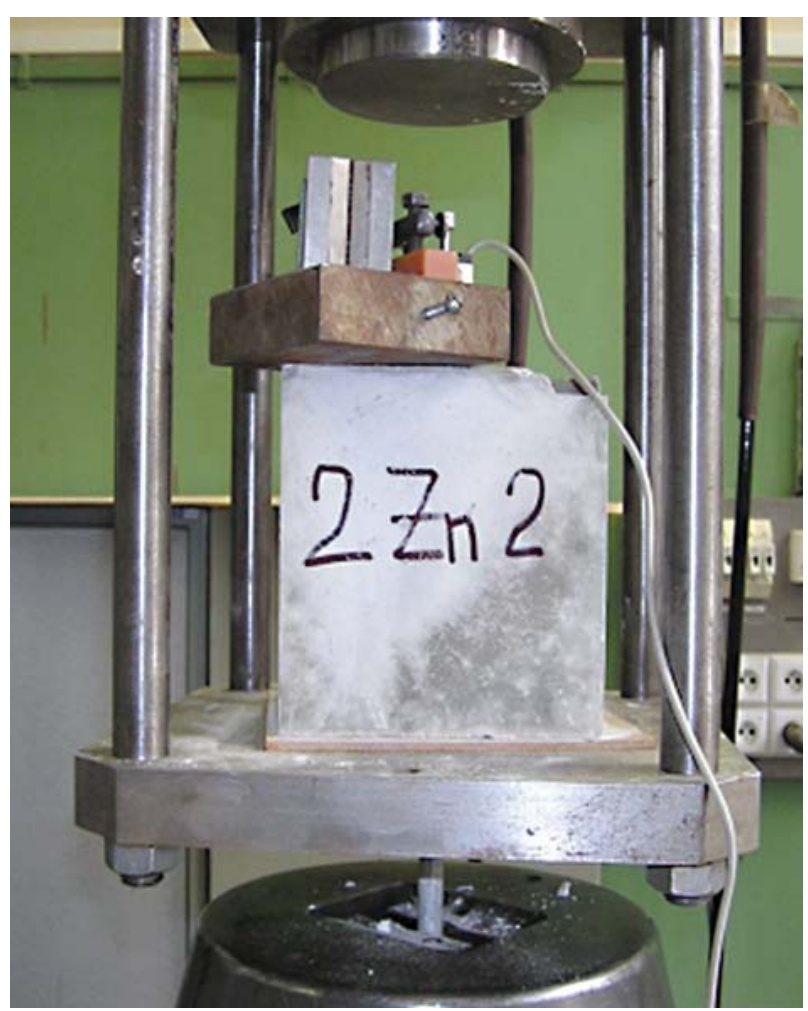

Obr. 5. Uspořádání experimentu pro zkoušení soudržnosti hladkých prutů s betonem

Fig. 5. Pull out test

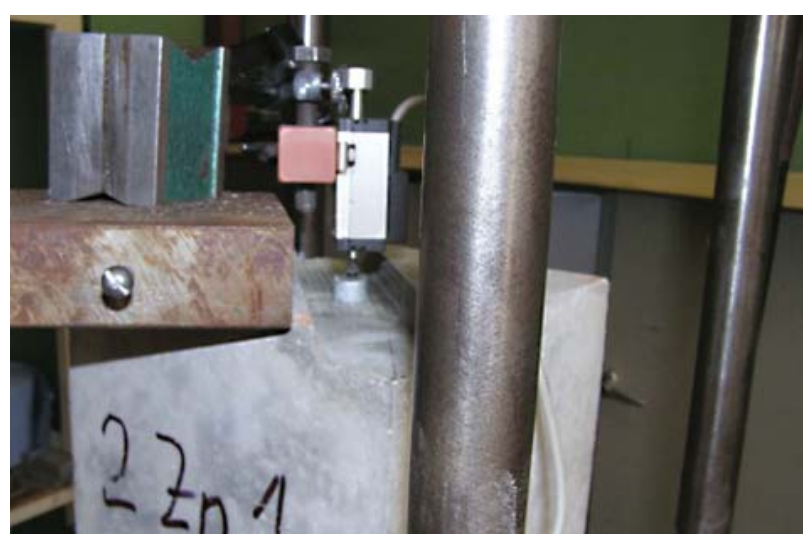

Obr. 6. Detailní snímek snímače posunu LVDT

Fig. 6. Detail image of the dilatometer 


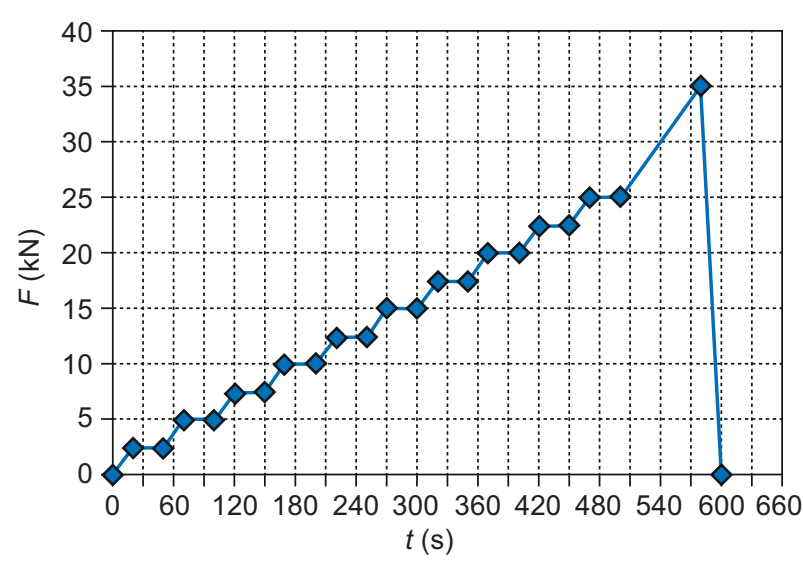

Obr. 7. Schéma průběhu zatěžování

Fig. 7. Example of the load record

\section{VÝSLEDKY A DISKUZE}

Vzhled povlaku z příčného řezu žárově zinkovaného prutu je zobrazen na Obr. 8 (optická mikroskopie) a Obr. 9. a Obr. 10 (elektronová mikroskopie). Ze snímků je zřejmé, že povlak žárového zinku má tloušt'ku $85 \pm 15 \mu \mathrm{m}$. Což překračuje minimální tloušt'ku povlaku dle průměru ocelového prutu $(d=12 \mathrm{~mm})$ podle ČSN EN ISO 1461 [56]. V povlaku dominuje jednoznačně fáze zeta $\left(\zeta-\mathrm{FeZn}_{13}\right)$, která zabírá přibližně $80 \%$ tloušt'ky celého povlaku. Tato fáze má palisádovitý charakter $\left(\mathrm{FeZn}_{13}-\right.$ krystaluje pro kovy v atypické jednoklonné krystalové soustavě) a její zvýšená tloušt'ka v povlaku zvyšuje jeho tvrdost, ale zároveň navyšuje i jeho křehkost [57, 58]. Při mechanickém zatěžování se jednotlivé vnější krystalové útvary mohou oddělit od povlaku (Obr. 9).

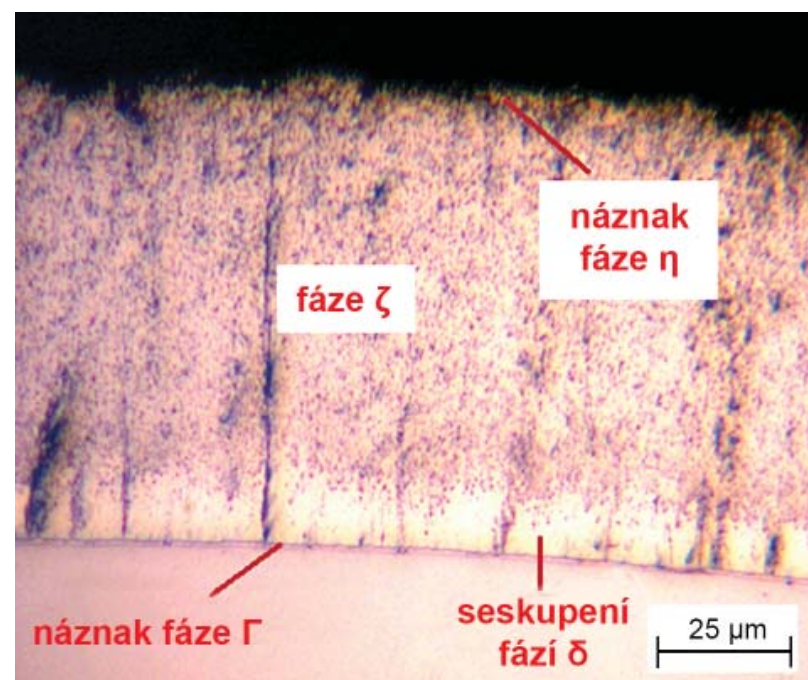

Obr. 8. Optická mikroskopie příčného řezu povlakem žárového zinku s označením vytvořených intermetalických fází $\mathrm{Fe}-\mathrm{Zn}$

Fig. 8. Optical image of the cross cut of the galvanized sample
Skutečnost, že povlak je tvořen především fází $\zeta$, dokládá i bodová EDS analýza (Obr. 11. a Tab. 5. a dále Obr. 12 a Obr. 13). Nejspodnější vrstva povlaku je tvořena náznakem fáze $\Gamma\left(\mathrm{Fe}_{3} \mathrm{Zn}_{10}\right), \mathrm{s}$ určitostí nelze vyloučit ani fázi $\Gamma_{1}\left(\mathrm{Fe}_{5} \mathrm{Zn}_{21}\right)$, a náznakem seskupení fází $\delta\left(\delta_{1 \mathrm{k}}-\mathrm{FeZn}_{7}\right.$ a $\left.\delta_{1 \mathrm{p}}-\mathrm{Fe}_{13} \mathrm{Zn}_{126}\right)$ [57]. Vliv těchto fází na korozi povlaku v čerstvém alkalickém prostředí betonu není možný, rovněž svými mechanickými vlastnostmi nebudou mít rozhodující vliv na soudržnost hladkých prutů $\mathrm{s}$ betonem.

Je velice pravděpodobné, že nejsvrchnější část zinkového povlaku není tvořena fází $\eta$ (tuhý roztok železa v zinku; obsah železa pouze $0,03 \mathrm{hm}$. \% [45, 57]), nebo nepokrývá povrch vrstvy fáze $\zeta$ souvisle. Tuto skutečnost potvrzuje matný vzhled pozinkovaných prutů, bez náznaku kovového lesku vrstvy prakticky čistého zinku.

Povlak žárového zinku vyloučený na povrchu hladkých ocelových prutů nedosahuje nejvyšší možné jakosti. Důvodem je skutečnost, že nejsou jednoznačně patrné, tj. vykrystalizované, fáze $\Gamma$ (přesněji $\Gamma+\Gamma_{1}$ ) a fáze $\delta$ (přesněji $\delta_{1 \mathrm{k}}+\delta_{1 \mathrm{p}}$ ), dále pak prakticky není přítomna fáze čistého zinku (přesněji fáze ๆ) a dominantní tloušt'ku povlaku reprezentuje fáze $\zeta$. Jakostnější povlaky s lepšími mechanickými vlastnostmi (především nižší křehkostí) mají větší podíl seskupení fází $\delta[45,57,58]$.

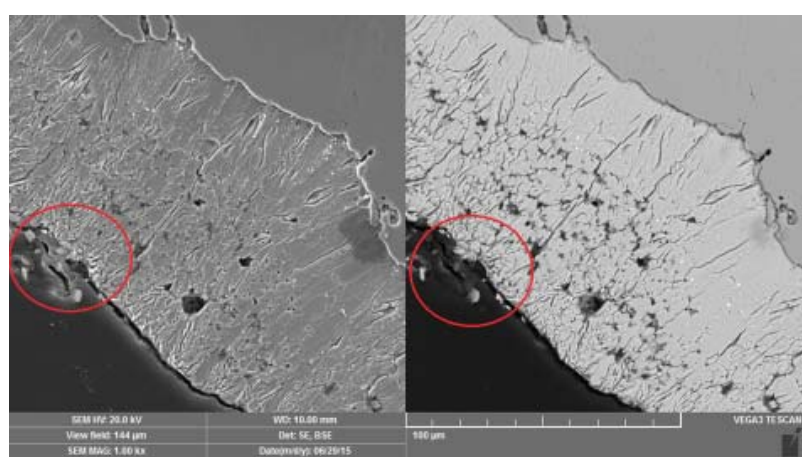

Obr. 9. Vzhled povlaku žárového zinku získaný metodou SEM $v$ režimu SE a BSE (s vyznačením odtržených krystalických útvarů z vrchní části povlaku)

Fig. 9. SEM images of the zinc coating



Obr. 10. Další snímek vzhledu povlaku žárového zinku získaný metodou SEM v režimu SE a BSE

Fig. 10. SEM images of the zinc coating 
Protože povlak obsahuje méně dobře vykrystalizované fáze $\Gamma$ a fáze $\delta$ a naopak $\mathrm{v}$ povlaku dominuje fáze $\zeta$, je možné, že jeho tvorbu podmínil negativní jev vlivu obsahu křemíku a fosforu na jakost povlaku, tzv. Sandelinův efekt (prudký nárůst tloušt'ky povlaku a tvorby jednofázové struktury ze $\zeta$ fáze; nežádoucí obsah křemíku 0,03-0,12 hm. \%). Podle obsahu křemíku v oceli (Tab. 4.) je použitá ocel sice uklidněná křemíkem, ale v tzv. Sebistyho oblasti (obsah křemíku od 0,15-0,25 hm. \%), takže by se u ní Sandelinův efekt neměl projevit. Rovněž obsah fosforu je spíše nižší, tj. rovněž on by neměl podněcovat $\mathrm{k}$ tvorbě jednofázové struktury. Nicméně je nutné poznamenat, že obsah

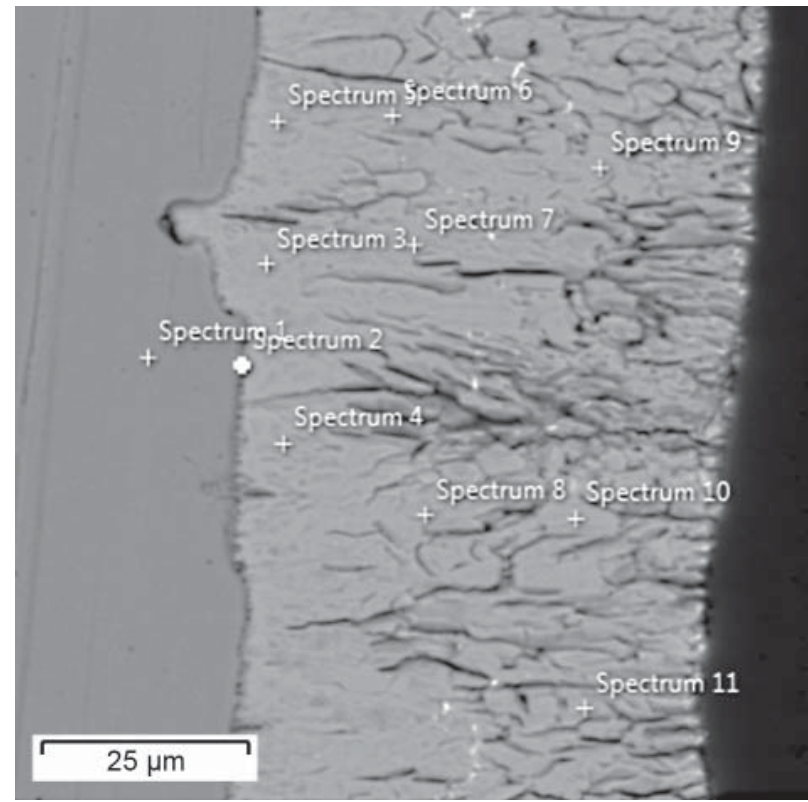

Obr. 11.Lokalizace jednotlivých bodových analýz metodou EDS

Fig. 11. Spots of EDS analyses

Tab. 5. Vyhodnocení obsahu Fe a Zn v jednotlivých bodových spektrech (Obr. 11) / Results of EDS analyses in single spots

\begin{tabular}{|c|c|c|}
\hline Lokalizace & Obsah Fe (hm. \%) & Obsah Zn (hm. \%) \\
\hline Spektrum 1 & 99,1 & 0,4 \\
\hline Spektrum 2 & 58,7 & 41,0 \\
\hline Spektrum 3 & 11,8 & 88,2 \\
\hline Spektrum 4 & 13,0 & 87,0 \\
\hline Spektrum 5 & 12,8 & 87,2 \\
\hline Spektrum 6 & 8,8 & 91,2 \\
\hline Spektrum 7 & 8,6 & 91,4 \\
\hline Spektrum 8 & 7,9 & 92,1 \\
\hline Spektrum 9 & 7,7 & 92,3 \\
\hline Spektrum 10 & 7,5 & 92,5 \\
\hline Spektrum 11 & 8,6 & 91,4 \\
\hline
\end{tabular}

Koroze a ochrana materiálu 59(2) 53-65 (2015) křemíku v použité oceli je již téměř na hranici Sebistyho oblasti. Na skladbu povlaku mohla mít negativní vliv i nedokonalá předúprava povrchu $\mathrm{v}$ zinkovně, především pak moření v kyselině chlorovodíkové.

Výsledky pevnosti v tlaku vytvořených betonů ze dvou zmíněných záměsí (krychelná pevnost) zobrazuje Tab. 6. Dle výše zmiňovaných normativů lze beton záměsi číslo 1 zařadit do pevnostní tř́ídy $\mathrm{C} 40 / 50$. Beton záměsi 2 lze zařadit do pevnostní třídy C45/55. Rozdíl $\mathrm{v}$ dosažených pevnostech mezi záměsí číslo 1 a záměsí číslo 2 je pravděpodobně způsoben cementem. Přestože

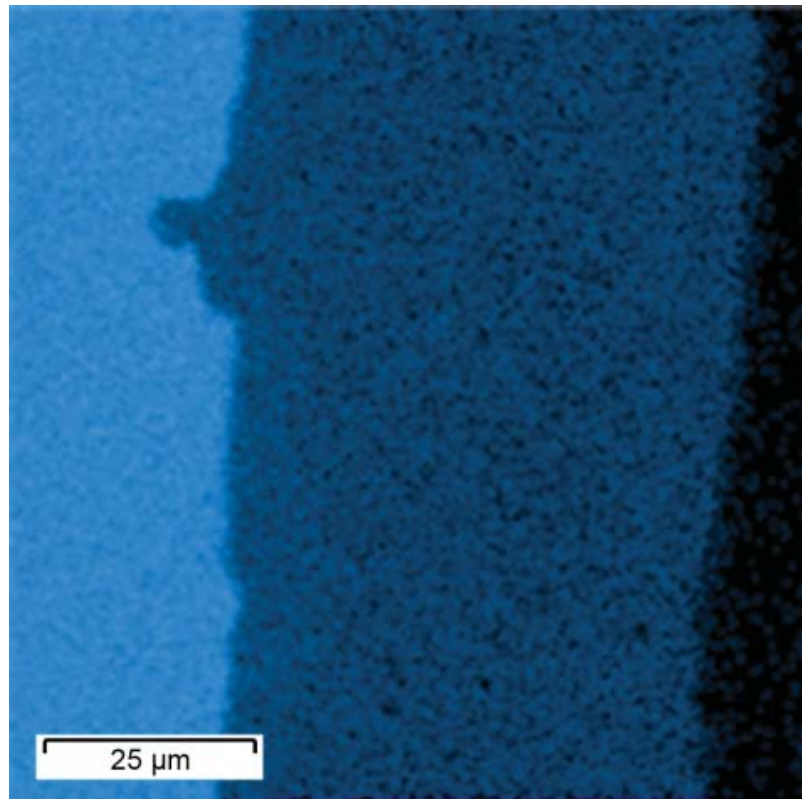

Obr. 12.Zastoupení Fe v povlaku (zjištěno analýzou EDS) Fig. 12. Fe-EDS map



Obr. 13. Zastoupení Zn v povlaku (zjištěno analýzou EDS) Fig. 13. $\mathrm{Zn}-\mathrm{EDS}$ map 
byl pro obě záměsi použit shodný cement (CEM II/B-S 32,5 R (Č́žkovice)), byl cement dávkován pro každou záměs z jiného pytle.
Při ,vytahovací” zkoušce soudržnosti byly měřeny křivky závislosti tahové síly v ocelovém prutu (která musí být v rovnováze se smykovým napětím mezi prutem

Tab. 6. Detailní zobrazení rozměrů zkušebních těles a výsledků pevnosti betonu v tlaku (krychelná pevnost) / Detail dimensions of samples and results of the test

\begin{tabular}{|c|c|c|c|c|c|c|c|}
\hline \multirow{2}{*}{ Označení vzorku } & \multicolumn{3}{|c|}{ Rozměry } & \multirow{2}{*}{$\begin{array}{c}\text { Hmotnost } \\
\text { (g) }\end{array}$} & \multirow{2}{*}{$\begin{array}{c}\text { Objemová hmotnost } \\
\left(\mathrm{kg} \mathrm{m}^{-3}\right)\end{array}$} & \multirow{2}{*}{$\begin{array}{c}\text { Tlaková síla } \\
(\mathrm{kN})\end{array}$} & \multirow{2}{*}{$\begin{array}{l}\text { Napětí v tlaku } \\
\text { (MPa) }\end{array}$} \\
\hline & b (mm) & h (mm) & I (mm) & & & & \\
\hline $1-1$ & 150,0 & 151,7 & 150,1 & 8132 & 2410 & 1415 & 62,2 \\
\hline $1-2$ & 149.9 & 151.7 & 150,0 & 8307 & 2440 & 1373 & 60,4 \\
\hline $1-3$ & 149.9 & 152,7 & 149,9 & 8303 & 2420 & 1426 & 62,3 \\
\hline \multicolumn{5}{|l|}{ Průměrná hodnota: } & 2420 & & 61,5 \\
\hline $2-1$ & 149,0 & 150,1 & 149,1 & 8065 & 2420 & 1266 & 56,6 \\
\hline $2-2$ & 150,6 & 150,6 & 150,3 & 8311 & 2440 & 1277 & 56,3 \\
\hline $2-3$ & 150,0 & 150,4 & 149.9 & 8166 & 2410 & 1264 & 56,0 \\
\hline \multicolumn{5}{|l|}{ Průměrná hodnota: } & 2420 & & 56,5 \\
\hline
\end{tabular}

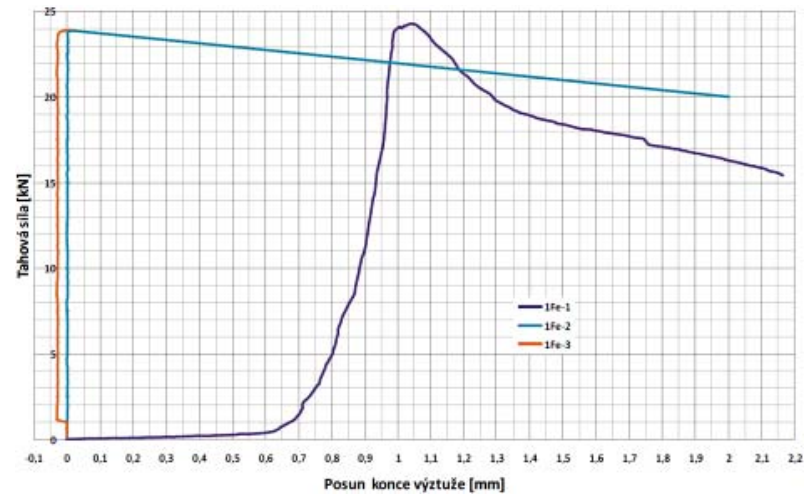

Obr. 14.Zatěžovací tahové křivky ocelových prutů bez povlaku při měření napětí v soudržnosti s betonem (1. záměs) Fig. 14. Stress/strain curves of steel rebars/concrete bond strength (1. mixture)

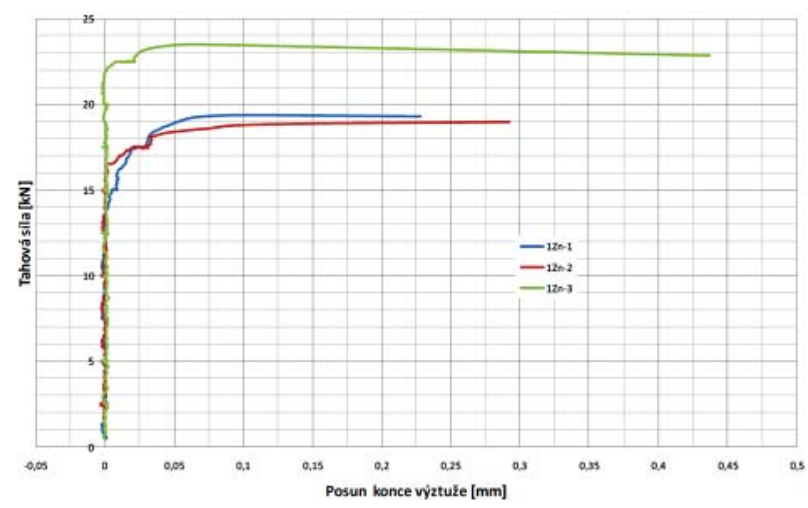

Obr. 15.Zatěžovací tahové křivky ocelových prutů žárově zinkovaných při měření napětí v soudržnosti s betonem (1. záměs)

Fig. 15. Stress/strain curves of galvanized steel rebars/concrete bond strength (1. mixture)

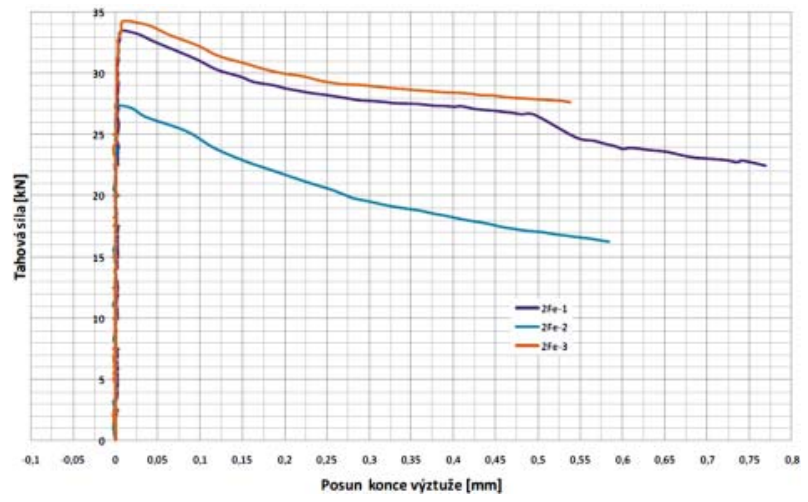

Obr. 16.Zatěžovací tahové křivky ocelových prutů bez povlaku při měření napětí v soudržnosti s betonem (2. záměs) Fig. 16. Stress/strain curves of steel rebars/concrete bond strength (2. mixture)

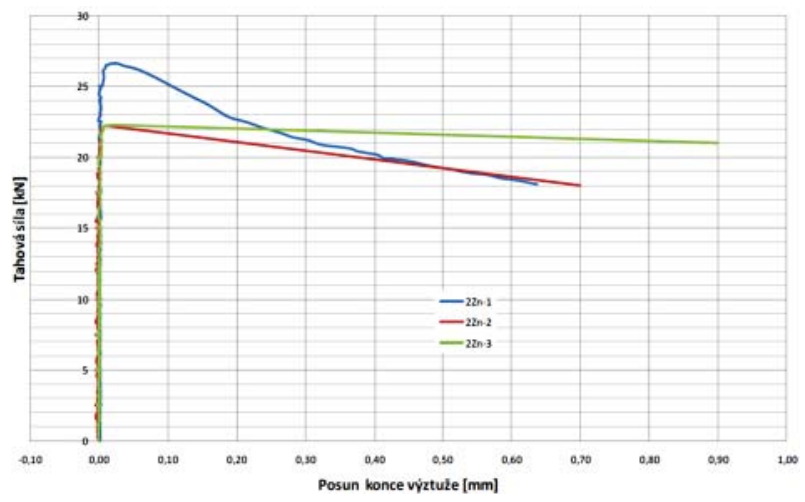

Obr. 17. Zatěžovací tahové křivky ocelových prutů žárově zinkovaných při měření napětí v soudržnosti s betonem (2. záměs)

Fig. 17. Stress/strain curves of galvanized steel rebars/concrete bond strength (2. mixture) 
a betonem v krychli) a posunem výztuže v betonu. Tyto křivky jsou na Obr. 14-17. Každá dvojice křivek je vždy pro jednu záměs. Tedy vzorky označené jako $1 \mathrm{Fe}$-x nebo $1 Z n-x$ jsou z 1 . záměsi a analogicky vzorky značené jako 2 Fe-x nebo 2Zn-x jsou z 2. záměsi.

Vzorek 1Fe-1 (fialová křivka Obr. 14) byl řízen deformací a nikoli dle zatěžovacího schématu. Tento vzorek byl právě prvním zkoušeným vzorkem a byl použit pro zjištění orientačního napětí v soudržnosti, která následně byla použita pro stanovení zatěžovacího schématu. Záznam posunu výztuže v tomto př́ípadě byl sledován snímačem posunu LVDT, který měří posun čelistí hydraulického válce na spodní straně zkušebního stroje MTS 500 kN. Ostatní měření posunu výztuže byla již měřena druhým snímačem posunu LVDT B20 (úchylkoměr) umístěném svou základnou na zkušební krychli (Obr. 6).

Z maximálního silového zatížení ocelového prutu v tahu $\underline{F}$ byla pro jednotlivé pruty dle ČSN 731328 [43] vypočteno napětí v soudržnosti $\underline{\tau}[\mathrm{MPa}]$ dle (6):

$$
\tau=\frac{F}{d \cdot \pi \cdot l}
$$

kde $F$ je maximální naměřenou tahovou sílou, $d$ jmenovitý průměr výztuže $(d=12 \mathrm{~mm})$ a $l$ kotevní délku ( $l \sim 140 \mathrm{~mm})$. Jednotlivá naměřená napětí v soudržnosti byla zprůměrována a zanesena do srovnávacích sloupcových diagramů pro každou záměs (Obr. 18. a Obr. 19.).

Z výsledků je zřejmé, že pro obě záměsi vycházejí nižší naměřená průměrná napětí v soudržnosti $\underline{\tau}[\mathrm{MPa}]$ pro ocel opatřenou povlakem žárového zinku. Přičemž vyšší naměřené soudržnosti jsou pro oba druhy prutů v 2. záměsi, což odpovídá vyšší hodnotě (C45/55) zjištěné pevnostní trrídy betonu druhé záměsi (Tab. 6.). Hutnější beton poskytuje vyšší adhezivní faktor $f_{a d}$ (rovnice (5)), což se projeví na vyšší průměrné naměřené hodnotě napětí v soudržnosti.

Z literatury je zřejmé, že fáze $\zeta$ (nejsvrchnější vrstva povlaku na zinkovaných prutech - Obr. 8.) koroduje velice intenzivně $\mathrm{v}$ modelových pórových roztocích betonu o $\mathrm{pH} 13,0$. Tato fáze není schopna přechodu do koroze v pasivním stavu, tj. korozní produkty na bázi $\mathrm{Ca}\left[\mathrm{Zn}(\mathrm{OH})_{3}\right]_{2} \cdot 2 \mathrm{H}_{2} \mathrm{O}$ nejsou schopny její povrch účinné zapasivovat $[9,35]$. Obvykle se tvrdí, že intermetalické fáze $\mathrm{Fe}-\mathrm{Zn}$ jsou v modelových pórových roztocích méně odolné než fáze $\eta$ nebo čistý zinek $[60,61]$.

Lze se tedy oprávněně domnívat, že v prvopočátku uložení pozinkovaných prutů do čerstvého betonu došlo $\mathrm{k}$ intenzivní korozi zinkového povlaku v aktivním stavu za vývoje vodíku (1). Vodík způsobuje naplynění cementového tmelu na fázovém rozhraní. To se projeví ve zvýšení pórovitosti cementového tmelu na fázovém rozhraní, což má za následek snížení adhezního faktoru $\mathrm{f}_{\mathrm{ad}}$ (rovnice 5) a tedy snížení soudržnosti výztuže s betonem.

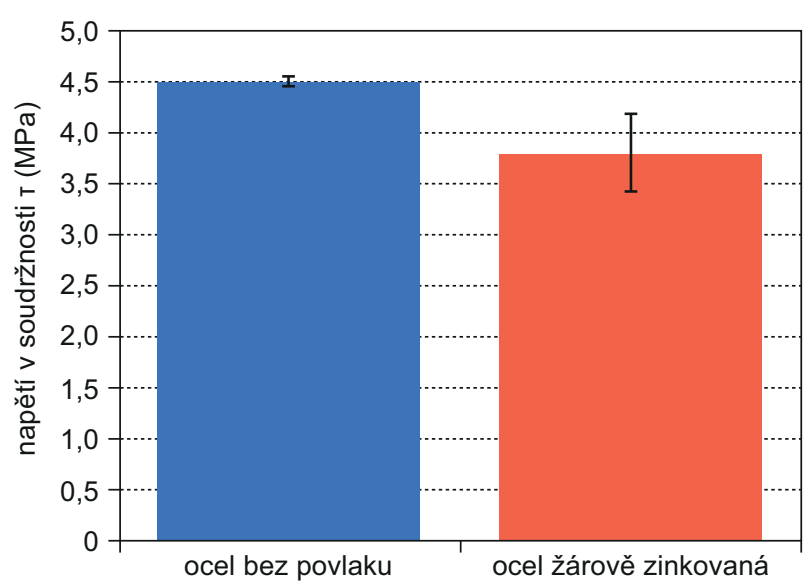

Obr. 18.Srovnávací diagram průměrného naměřeného napětí $v$ soudržnosti pro oba druhy hladkých prutů a pro 1. záměs

Fig. 18. Average bond strength of steel and galvanized steel (1. mixture)

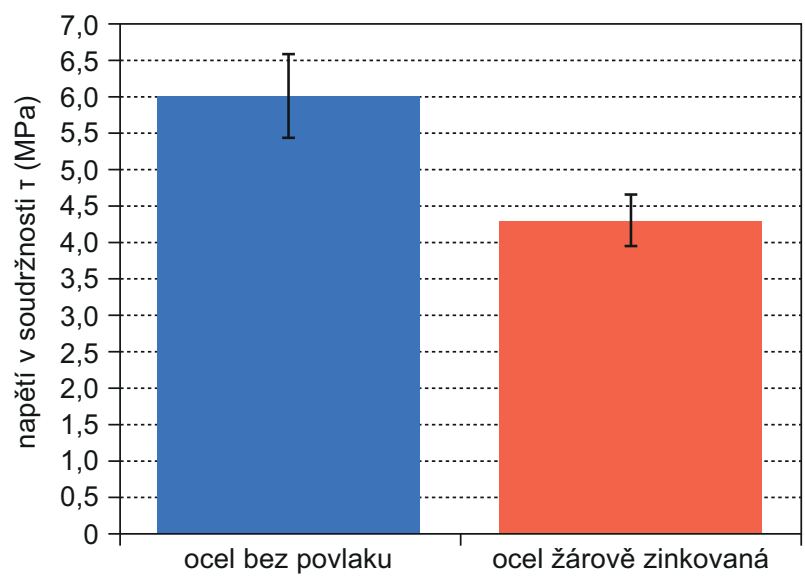

Obr. 19.Srovnávací diagram prưměrného naměřeného napětí $v$ soudržnosti pro oba druhy hladkých prutů a pro 2. záměs

Fig. 19. Average bond strength of steel and galvanized steel (2. mixture)

Vliv chloridových $\left(\mathrm{Cl}^{-}\right)$a chromanových $\left(\mathrm{CrO}_{4}{ }^{2-}\right)$ anionů na korozní chování zinkového povlaku v čerstvém betonu je minimální. Obsah chromanů v použitém cementu je pod uváděnou spodní hranici jeho obsahu [51] zaručující přechod koroze zinku do pasivního stavu $\mathrm{v}$ čerstvém betonu.

Dále je nezbytné diskutovat vliv korozních produktů na bázi $\mathrm{Ca}\left[\mathrm{Zn}(\mathrm{OH})_{3}\right]_{2} \cdot 2 \mathrm{H}_{2} \mathrm{O}$. Tyto korozní produkty vznikají na povrchu zinkového povlaku a svým růstem poškozují cementový tmel. Při zatěžování dojde k šíření distorzní trhliny nepojivou vrstvou těchto korozních produktů. Tato skutečnost je zjednodušeně zobrazena na Obr. 20. 
Protože nejsvrchnější vrstva povlaku žárového

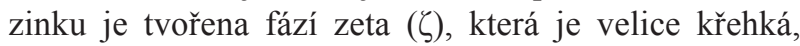
může se při zatěžování distorzní trhlina šiřit podél hranic krystalů nejsvrchnější části této fáze (Obr. 21). Možná je samozřejmě kombinace obou mechanizmů realizovaných samostatně $\mathrm{v}$ různých částech kotevní délky pozinkovaného prutu $\mathrm{v}$ betonu. Distorze podél myšlené čáry usnadňuje vytažení pozinkovaného prutu.

$\mathrm{V}$ nedávné době byl diskutován vliv trvalého prístupu vody na kinetiku koroze zinku $\mathrm{v}$ prostředí reálného betonu. $Z$ výsledků stanovené korozní rychlosti rezistometrickou metodou vyplývá, že kinetika koroze zinku $\mathrm{v}$ tomto prostředí je ovlivněna transportem vody, tj. pokud vzorky ztvrdlého betonu se zinkovými čidly jsou zpětně uloženy pod vodní hladinu, korozní rychlost zinku opět vzrůstá [62].

Protože vzorky betonových těles byly uloženy pod vodní hladinou, lze předpokládat, že koroze zinkového povlaku probíhala intenzivně po dobu 28 dnů

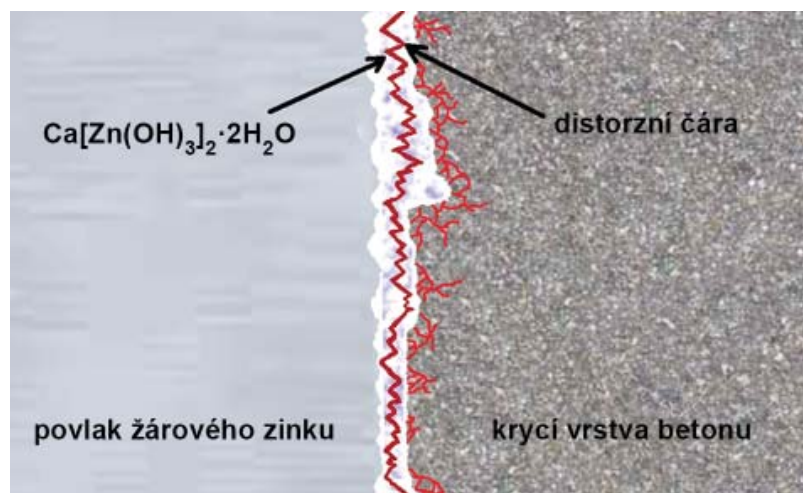

Obr. 20. Statické schéma zobrazující distorzi v korozních produktech z $\mathrm{Ca}\left[\mathrm{Zn}(\mathrm{OH})_{3}\right]_{2}$ mezi zinkovaným prutem a krycí vrstvou betonu při zatěžování v průběhu zkoušek soudržnosti

Fig. 20. Static scheme of the rupturing of corrosion products between galvanized rebar and concrete

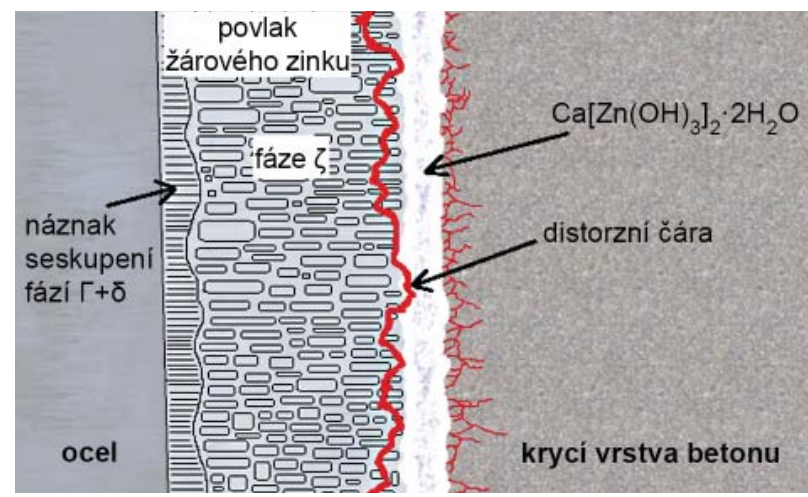

Obr. 21. Statické schéma zobrazující distorzi v nejsvrchnější části fáze $\zeta$ mezi zinkovaným prutem a krycí vrstvou betonu při zatěžování v průběhu zkoušek soudržnosti

Fig. 21. Static scheme of the rupturing in $\zeta$-phase between galvanized rebar and concrete (fáze $\zeta$ je méně korozně odolná než čistý zinek). Po tuto dobu došlo $\mathrm{k}$ výraznému nárůstu tloušt'ky korozních produktů na bázi $\mathrm{Ca}\left[\mathrm{Zn}(\mathrm{OH})_{3}\right]_{2} \cdot 2 \mathrm{H}_{2} \mathrm{O}$ a snížení tloušt'ky povlaku na ocelovém prutu. $Z$ tohoto důvodu mohlo spíše dojít k dřivějšímu posunutí povlakované výztuže vlivem koroze zinkového povlaku, tj. distorzí podél korozních produktů vytvořených mezi výztuží a betonem (Obr. 20).

Ze snímků zkušebních těles po zkoušce soudržnosti je zřejmé, že pruty nebyly zcela dokonale kotveny do osy těles (Obr. 22-24). Nasvědčuje tomu destrukce betonu v blízkosti zatěžovaného prutu (detail Obr. 24). Nebyla tedy jednoznačně splněna základní podmínka pro objektivní zkoušení soudržnosti výztuže s betonem, tj. dokonalé kotvení hladkých prutů do os zkušebních těles. Nicméně z Obr. 22 a Obr. 23. je zřejmé, že to byly především zinkované výztuže, které se ve své ploše kotevní délky opíraly o ztvrdlý styčný povrch betonu.

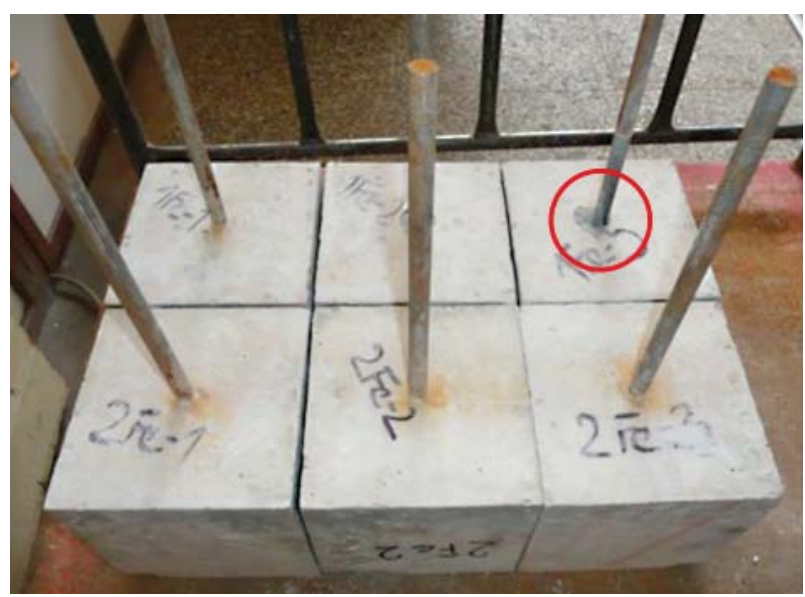

Obr. 22. Vzhled zkušebních těles po zkoušce soudržnosti ocel bez povlaku (vyznačení viditelných míst destrukce betonu v blízkosti zatěžovaného prutu)

Fig. 22. Samples with steel rebars after the test (concrete rupture highlighted)

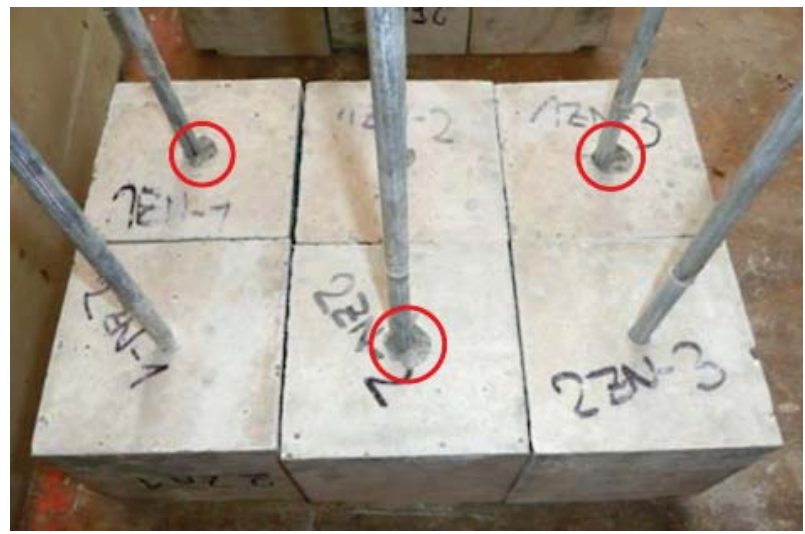

Obr. 23. Vzhled zkušebních těles po zkoušce soudržnosti ocel žárově zinkovaná (vyznačení viditelných míst destrukce betonu v blízkosti zatěžovaného prutu)

Fig. 23. Samples with galvanized steel rebars after the test (concrete rupture highlighted) 
Nicméně i vnesení této chyby měření do výsledků zkoušek soudržnosti naznačuje, že hladké pozinkované prutu soudrží s betonem hůře než pruty bez povlaku.

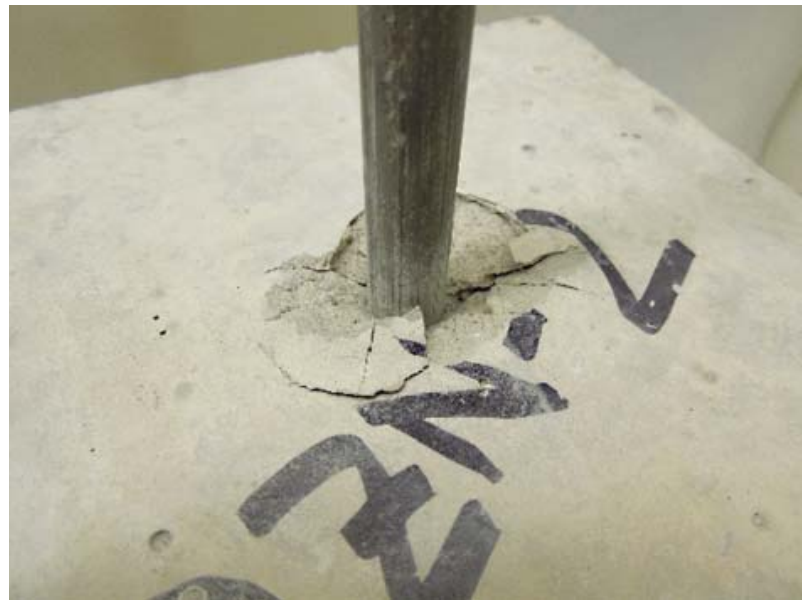

Obr. 24. Detail destrukce betonu $v$ blízkosti zatěžovaného prutu vzniklé v průběhu zkoušky soudržnosti

Fig. 24. Detail of the concrete rupture after the test

\section{ZÁVĚR}

Žárové zinkování povrchu ocelových výztuží může prodloužit životnost betonových konstrukcí. Důvodem je vyšší odolnost povlaku žárového zinku vůči karbonataci betonu a působení chloridů. Je důležité připomenout, že povlak pouze prodlužuje dobu do aktivace podkladové oceli.

Ovšem obava, že využití pozinkované výztuže může vyvolat snížení soudržnosti s betonem, je také oprávněná. Toto snížení soudržnosti výztuže s betonem je vyvoláno korozí zinkového povlaku v čerstvém betonu, tj. vývojem plynného vodíku (zvýšení pórovitosti cementového tmelu) a expanzí korozních produktů na bázi nepojivé fáze $\mathrm{Ca}\left[\mathrm{Zn}(\mathrm{OH})_{3}\right]_{2} \cdot 2 \mathrm{H}_{2} \mathrm{O}$. Je ovšem také evidentní, že koroze zinkového povlaku velice úzce souvisí s hodnotou $\mathrm{pH}$ alkalického pórového roztoku čerstvého betonu, a nelze vyloučit, že ji mohou ovlivňovat i některé specifické př́sady (plastifikátory, provzdušňovací látky, ztekucovadla atd.).

Zcela kritické mohou být ty části konstrukce, kde dochází k trvalému smáčení betonového povrchu vodou. $\mathrm{V}$ těchto případech může koroze zinkového povlaku rychle ztenčovat průměr použité výztuže, což nutně povede $\mathrm{k}$ výraznému snižování soudržnosti povlakované výztuže s betonem.

Při navrhování betonových konstrukcí s pozinkovanou výztuží by se měly dodržovat konstrukční zásady vyztužování, které zohledňují nebezpečí snížení soudržnosti této výztuže s betonem.

\section{Poděkování}

Realizováno za finanční podpory Grantové agentury České republiky, reg. číslo 14-20856S.

\section{LITERATURA}

1. Tonini, D.E.; et al. Chloride corrosion of steel in concrete, American Society for Testing and Materials, Baltimore 1977, str. 17.

2. Pytlík, P.; Technologie betonu, $1^{\text {st }}$ ed.; Vysoké učení technické v Brně, Brno 2000, str. 178.

3. Collepardi, M.; Moderní beton, $1^{\text {st }}$ ed.; ČKAIT, Pelhřimov 2009, str. 117.

4. Bertolini, L.; et al. Corrosion of Steel in Concrete (Prevention, Diagnosis, Repair), WILEY-VCH Verlag GmBH and Co. KGaA, Weinheim 2004, str. 26.

5. Böhni, H.; et al. Corrosion in reinforced concrete structures, $1^{\text {st }}$ ed.; Woodhead Publishing Ltd. and CRC Press LLC: Woodhead Publishing Ltd, 2005, str 81.

6. Novák, P.; et al. Koroze ocelové výztuže v betonu, Koroze a ochrana materiálu, 1996, 40 (1), 2-7.

7. Kouřil, M.; et al. Korozivzdorné oceli pro výztuže betonu, Koroze a ochrana materiálu 2002, 46 (3), 62-67.

8. Pokorný, P.; Předpokládaná účinnost konverzních povlaků proti aktivaci zinkované oceli $\mathrm{v}$ modelových pórových roztocích betonu, Koroze a ochrana materiálu 2013, 57 (4), 115-126.

9. Yeomans, S. R. Galvanized steel reinforcement in concrete, $2^{\text {nd }}$ ed.; Elsevier, Canberra 2004, str 72.

10. Eriksson, H., Hirnová A.; Př́ručka žárového zinkování, $3^{\text {rd }}$ ed.; AČSZ, Ostrava 2009.

11. Fratesi, R.; Galvanized reinforcing steel bars in concrete, COST 521 Workshop, Luxembourg 2002.

12. Page, C.L.; et al. Corrosion behavior of zinc coated steel in silica fume concrete, Corrosion Conference Trondheim, $1989,887-896$

13. Bautista, A., Gonzales, J.A. Analysis of the protective efficiency of galvanizing agains corrosion of reinforcements embedded in chloride contaminated concrete. Cement and Concrete Reaserch 1996, 26 (2), 215-223.

14. El-Hawary, M. M.; et al. Evaluation of bond strength of epoxy-coated bars in concrete exposed to marine environment, Construction and Building Materials, 1999, 13, $357-362$.

15. Kobayashi, K.; et al. Experimental studies on epoxy coated reinforcing steel for corrosion protection, The International Journal of Cement Composites and Lightweight Concrete, 1984, 6 (2), 99-116.

16. Assaad, J. J.; et al. Bond stregth of epoxy-coated bars in underwater concrete, Construction and Building Materials 2011, 30, 667-674.

17. Cusens, A.; et al. Pullout Tests of Epoxy-Coated Reinforcement in Concrete, Cement \& Concrete Composites, 1992, 14, 269-276.

18. Swamy, R.; Epoxy coated rebars-The panacea for steel corrosion in concrete. Construction \& Building Materials 1989, 3 (2), 86-91.

19. Pokorný, P.; et al. Faktory ovlivňující soudržnost povlakované výztuže s betonem, TriboTechnika 2014, 2, 80-82. 
20. Kouřil, M. Soudržnost zinkované oceli s betonem. Koroze a ochrana materiálu 2007, 51 (4), 80-83.

21. Pokorný, P.; Vliv koroze zinkované oceli na soudržnost s betonem, Koroze a ochrana materiálu 2012, 56 (4), 119-135.

22. Bartoníček, R.; Koroze a protikorozní ochrana kovů $1^{\text {st }}$ ed.; Academia - nakladatelství Československé akademie věd, Praha 1966.

23. Zhang, X.; Corrosion and electrochemistry of zinc; Plenum Press: New York, 1996.

24. Macías, A.; Andrade, C.; Corrosion of galvanized steel in dilute $\mathrm{Ca}(\mathrm{OH}) 2$ solutions ( $\mathrm{pH} 11,1-12,6)$, British Corrosion Journal 1987, 22 (3), 162-171.

25. Macias, A., Andrade C.; Corrosion of galvanized steel reinforcements in alkaline solutions.(Part 1: Electrochemical results) British Corrosion Journal 1987, 22 (2).

26. Macias, A., Andrade C.; Corrosion of galvanized steel reinforcements in alkaline solutions.(Part 2: SEM study and identification of corrosion products) British Corrosion Journal 1987, 22 (2).

27. Blanco, M. T. Macias, A., Andrade C.; SEM study of the corrosion products of galvanized reinforcements immersed in solutions in the $\mathrm{pH}$ range 12,6-13,6 British Corrosion Journal 1984, 19 (1).

28. Macias, A. Andrade C.; Galvanized steel behaviour in $\mathrm{Ca}(\mathrm{OH})_{2}$ saturated solution containing $\mathrm{SO}_{4}$ ions. Cement and Concrete Reaserch 1987, 17, 307-316.

29. Porter, F.C.; Corrosion resistance of zinc and zinc alloys, $1^{\text {st }}$ ed., Marcel Dekkler, USA - North Carolina 1994.

30. Macias, A.; Equilibria of the chemical composition of the concrete pore solutions. Part I. Comparative study of synthetic and extracted solutions. 1987, 17 (2), 173-182.

31. Macias, A.; Andrade C. Stability of the calcium hydroxyzincate protective layer developed on galvanized reinforcements after a further increase of the $\mathrm{pH}$ value. 1986, 36 (204), 19-28.

32. Macias, A.; The behaviour of galvanized steel in chloridecontaining alkaline solutions-I. The influence of the cation. 1990, $30(4 / 5), 393-407$.

33. Wienerová, K.; et al. Koroze a ochrana zinkované oceli v prostředí betonu, Koroze a ochrana materiálu 2010, 54 (4), 148-154.

34. Pokorný, P.; Použití žárově zinkované výztuže betonu, Strojárstvo/Strojírenství 2014, 6, 100-101.

35. Short, N.R.; et al. Electrochemical studies on the corrosion of range of zinc alloy coated steel in alkaline solutions, Surface \& Coating Technology 1996, 79, 218-224.

36. Olmo, I.; et al. Influence of lead, zinc iron (III) and chromium (III) oxides on the setting time and strength development of Portland cement, Cement and Concrete Research 2001, 31, 1213-1219.

37. Takahashi, H.; et al. Hardening property of cement mortar adding heavy metal compound and solubility of heavy metal from hardened mortar. Cement and Concrete Research 1977, 7, 283-290.

38. Asavapisit, S.; et al. Solution chemistry during cement hydratation in the presence of metal hydroxides wastes. Cement and Concrete Research 1997, 27 (8), 1249-1260.

39. Arliguie, G.; et al. Etude de l'effet retardateur du zinc sur l'hydratation de la paste de ciment portland. Cement and Concrete Research 1982, 12, 79-86.

40. Rovnaníková, P. Problémy spojené s použitím pozinkované výztuže do betonu. Koroze a ochrana materiálu 2002, 46 (5), 104-107.
41. Belaid, F.; et al. Porous structure of the ITZ around galvanized and ordinary steel reinforcements, Cement and Concrete Research 2001, 31, 1561-1566.

42. Rovnaníková P., Bayer P.; Mikrostruktura cementového tmelu v okolí pozinkované výztuže, 9. konference žárového zinkování; Ed.; 2003; pp 57-62.

43. ČSN 73 1328. Stanovení soudržnosti oceli s betonem. Praha: Český normalizační institut, 1971. $11 \mathrm{p}$.

44. ČSN 73 1333. Zkoušení soudržnosti předpinaci výztuže s betonem. Praha: Český normalizační institut, 1990. 15 p.

45. Kuklík, V., Kudláček, J.; Žárové zinkování, $1^{\text {st }}$ ed., AČSZ, Praha 2014.

46. Kuklík, V.; Vybrané př́klady vad povlaků žárového zinku, TriboTechnika 2013, 6, 52-54.

47. http://www.galvanizeit.org/hot-dip-galvanizing/how-longdoes-hdg-last/in-concrete (cit. 2.7. 2015).

48. http://www.galvanizeit.org/uploads/publications/Performance_of_Galvanized_Steel_Products.pdf (cit. 2. 7. 2015)

49. http://www.galvanizedrebar.com/Documents/Publication/ Specifiers\%20Guide\%20To\%20Rebar\%200504.pdf (cit. 2. 7. 2015).

50. Bowsher B.; et al. Corrosion protection of reinforcing steels -Technical report fib - Bulletin 49, IFSC, Lousanne 2009.

51. Pokorný, P.; Kritická diskuze k vlivu př́́davku chemických látek do cementu na korozní chování zinkované oceli, Koroze a ochrana materiálu 2014, 58 (1), 31-35.

52. Andrade C.; et al. Protection systems for reinforcement, Bulletin D'Information N ${ }^{\circ} 211$, Comite Euro-International du Beton, Lausanne 1992.

53. ČSN EN 12390-2. Zkoušení ztvrdlého betonu - Č́ast 2: Výroba a ošetřování zkušebních těles pro zkoušky pevnosti.

54. ČSN EN 12390-3. Zkoušení ztvrdlého betonu - Č́st 3: Pevnost $v$ tlaku zkušebních těles.

55. ČSN EN 12390-7. Zkoušení ztvrdlého betonu - Č́st 7: Objemová hmotnost ztvrdlého betonu

56. ČSN EN ISO 1461. Žárové povlaky zinku nanášené ponorem na železných a ocelových výrobcích - Specifikace a zkušební metody

57. Pokorný, P.; et al. Description of structure of Fe-Zn intermetalic compounds present in hot-dip galvanized coatings on steel, Metalurgija 2015, 4, 707-710.

58. Brown, P. J.; The structure of the $\zeta$ - phase in the transicion metal - zinc alloy systems, Acta Crystallographica 1962, 15,608 .

59. Gellings, P.J., de Bree, E.W., Gierman, G.; Synthesis and Characterization of Homogeneous Intermetallic Fe-Zn Compounds, Part 2., International Journal of Materials Research 1979, 70 (5), 315-317

60. Sergi, G.; et al. Corrosion of galvanized and galvannealed steel in solutions of $\mathrm{pH} 9,0-14,0$. National Association of Corrosion Engineers (Presented during Corrosion/85) 1985, 618-624.

61. Swamy, R.N.; et. al. Corrosion behaviour of zinc alloy coated steel in hardened cement pastes, Proceedings of international conference held at the University of Sheffield: Corrosion and Corrosion protection of steel in concrete, Shefield Academic Press, 1994, 1287-1298.

62. Kučera, V.; et al. Kinetika dějů řídících korozi zinkované oceli v betonu (Laboratorní projekt I), VŠCHT 2015, 26 p. 